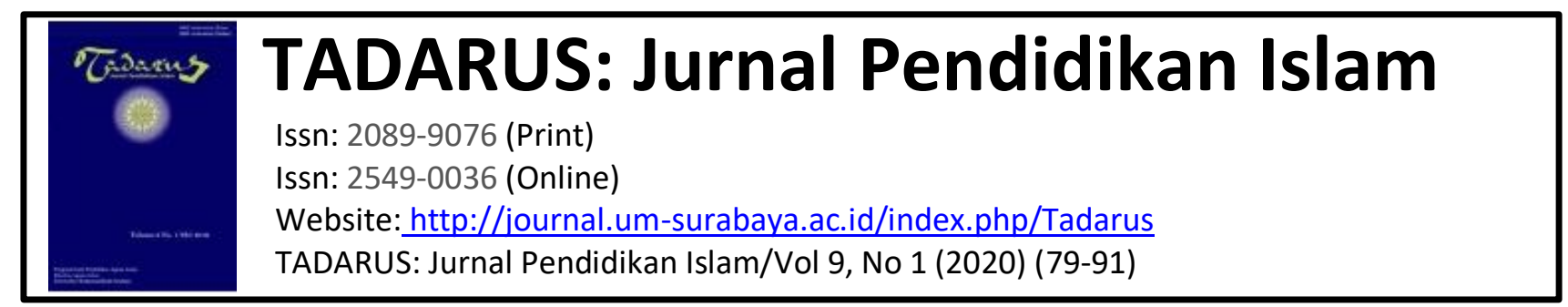

\title{
PENINGKATAN PRESTASI BELAJAR SISWA BROKEN HOME PADA MATA PELAJARAN PENDIDIKAN AGAMA ISLAM MENGGUNAKAN METODE NLP DI PHADUNGSIL WITTAYA SCHOOL THAILAND
}

${ }^{1}$ Nur Aini Mawa Indah, ${ }^{2}$ Moch Charis Hidayat

${ }^{1}$ mawa_indah@gmail.com, ${ }^{2}$ m.charishidayat@fai.um-surabaya.ac.id Program Studi Pendidikan Agama Islam, Universitas Muhammadiah Surabaya

\begin{abstract}
Abstrak
Metode NLP (Neuro Linguistic Programing) adalah salah satu cara komunikasi yang digunakan untuk mendidik atau mengarahakan anak didik yang wajib dimiliki tenaga pendidik sehingga dapat menggali potensi yang tersembunyi. Maka metode NLP dalam mengatasi anak Broken Home sangatlah penting, Karena anak Broken Home memiliki sifat yang cenderung tertutup sehingga potensi diri anak Broken Home sulit untuk di tampilkan. Sehingga tenaga pendidik bertanggung jawab untuk membimbing dan mengarahkan anak Broken Home untuk dapat menampilkan potensi dengan mengunakan metode komunikasi NLP
\end{abstract}

Kata Kunci: Metode Komunikasi NLP, Prestasi Belajar Siswa Broken Home

\section{Pendahuluan}

Keluarga merupakan tempat pendidikan pertama anak-anak mendapatkan pengalaman sejak kecil yang langsung akan digunakan sebagai bekal hidupnya yang akan datang, melalui latihan fisik, mental, sosial, emosional dan spiritual. Seperti juga yang ditulis didalam buku " Usulul Attarbiyah wa taklim juss 2" Sesungguhnya kewajiban pertama untuk mendidikan seorang anak adalah para orang tua berkewajiban untuk mengawasi anak mereka. Pendidikan orang tua yang diberikan sejak kecil mencantumkan atau mencerminkan masa depan seorang anak. ${ }^{1}$

Broken home sangat berpengaruh besar terhadap mental anak. Hal ini juga merusak jiwa anak secara perlahan-lahan dan membuat mereka menjadi susah untuk diatur, tidak disiplin, nakal, egois, dan brutal. Hal ini menjadi pengicu dari suatu kerusuhan karena dia ingin mencari simpati dari teman-temannya dan lingkungan sekitarnya, dan rasa egois yang tinggi anak merasa ingin menang sendiri.

\footnotetext{
1 Kulliyatul Mu'allimah Alislamiah, Usulul Attarbiyah Wata'lim Jus Assani, (Ponorogo: Pondok Modern Darussalam Gontor, 2007), 31.
} 
Pendidikan Agama Islam Secara alamiah adalah manusia tumbuh dan berkembang sejak dalam kandungan sampai meninggal, dengan cara mengalami banyak proses-proses, tahap demi tahap. Agama islam adalah asas, tiang atau pedoman setiap manusia di dunia ini, jika manusia tidak memiliki agama maka dia akan runtuh, hancur dan tersesat seperti rumah yang tidak ada pondasinya maka dia akan runtuh, hancur dan tidak kuat untuk berdiri seperti rumah yang ada pondasi tiangnya.

Dari latar belakang masalah tersebut pembentukan karakter anak merupakan sesuatu yang sangat penting atau urgent, oleh sebab itu pada penelitian ini penulis akan mencoba untuk berexperiment menggunakan metode NLP untuk membantu anak broken home dalam membentuk moral atau perilakunya agar lebih baik.

\section{Landasan Teori}

1. Pengertian NLP berdasarkan bahasa

Berdasarkan bahasa penyusunnya, NLP merupakan bentukan dari istilah neuro linguistic programming. Jika di urai, istilah itu akan mendapatkan sebagaimana dalam pendapat Ibrahim Elfiky yang dikutip oleh Ghannoe dalam bukunya yang berjudul buku pintar NLP menguraikan bahwa: "N" neuro, yaitu terkait system saraf seseorang atau corong penghubung panca indra manusia. "L" Linguistic, yaitu kemampuan alami berkomunikasi secara verbal dan nonverbal. "P" programming, yaitu mengacu pada pola pikir, perasaan, dan tindakan seseorang. ${ }^{2}$

Definisi NLP dalam Encyclopedia of Systemic NLP and NLP New Coding adalah pola-pola atau pemrograman yang diciptakan dari hubungan antara otak (neuro), bahasa (linguistic) dan kondisi tubuh (body state). Ditinjau dari perspektif NLP, hubungan tersebut akan mempengaruhi perilaku manusia yang efektif dan tidak efektif, dan sangat memengaruhi pembentukan mental individu yang adjustment dan maladjustment. ${ }^{3}$

Harris memberikan penjelasan tentang kerangka kerja NLP dengan versi berikut ini. NLP merupakan the experiental array (rangkaian pengalaman). Rangkaian ini terdiri atas lima unsur yang berkontribusi terhadap sebuah performance yaitu hasil (outcome), perilaku, mental, emosi, keyakinan, dan nilai. Kelima unsur ini berkaitan

\footnotetext{
${ }^{2}$ Ghannoe, Buku pintar NLP, (Jogjakarta: Flash Book, 2010), 18-20.

${ }^{3}$ Dilts, R dan Delozier, Enyclopedia of Systemic NLP an NLP New Coding. (USA: NLP University Press, 2000), 849
} 
erat dan membentuk sebuah sistem, sehingga unsur internal (pikiran dan perasaan) akan memengaruhi perilaku, dan perilaku akan menghasilkan sebuah hasil (outcome). ${ }^{4}$

\section{Keluarga Broken Home}

Broken home menurut kamus lengkap psikologi yaitu keluarga retak, rumah tangga berantakan. Keluarga atau rumah tangga tanpa hadirnya salah seorang dari ke dua orang tua (ayah atau ibu), disebabkan oleh meninggal, perceraian, meninggalkan keluarga dan lain sebagainya. ${ }^{5}$ Menurut Willis, Broken Home sering dikaitkan dengan krisis keluarga, yaitu kondisi yang sangat labil dalam keluarga, dimana komunikasi dua arah dalam kondisi demokratis sudah tidak ada. Quensel menambahkan bahwa istilah Broken Home biasanya untuk menggambarkan keluarga yang tidak harmonis dan tidak berjalan layaknya keluarga yang rukun dan sejahtera akibat sering terjadi konflik yang menyebabkan pada pertengkaran bahkan dapat berujung pada perceraian. Hal ini akan berdampak besar terhadap suasana rumah yang tidak lagi kondusif, orang tua tidak lagi perhatian terhadap anak-anaknya sehingga berdampak pada perkembangan remaja. ${ }^{6}$

3. Pendidikan Agama Islam

Menurut Zuhairini, Pendidikan Agama Islam adalah usaha sadar untuk membimbing ke arah pembentukan kepribadian peserta didik secara sistematis dan pragmatis, supaya hidup sesuai dengan ajaran Islam, sehingga terjadinya kebahagiaan dunia akhirat. ${ }^{7}$ Pendidikan Agama Islam memiliki tujuan untuk membangun dan membentuk manusia yang berkepribadian Islam dengan selalu mempertebaliman dan taqwa sehingga bisa berguna bagi bangsa dan agama. ${ }^{8}$

Dengan demikian, maka pengertian Pendidikan Agama Islam berdasarkan rumusan di atas adalah pembentukan perubahan sikap dan tingkah laku sesuai dengan petunjuk ajaran agama Islam. Sebagaimana yang pernah dilakukan Nabi dalam usaha menyampaikan seruan agama dengan berdakwah, menyampaikan ajaran, memberi contoh, melatih keterampilan berbuat, memberi motivasi dan menciptakan lingkungan sosial yang mendukung pelaksanaan ide pembentukan pribadi muslim. Untuk itu

\footnotetext{
4 Harris, C, NLP Made Easy. London: Element, 2003), 52

${ }^{5}$ J.P Chaplin, Kamus Lengkap Psikologi, (Raja Grafindo Persada, 2005), 71

${ }^{6}$ Save. M. Dagun, Psikologi Keluarga, (Jakarta, Rieneka Cipta, 2002), 103

${ }^{7}$ Zuhairini, Metodologi Pembelajaran Pendidikan Agama Islam, (Malang: UIN Press, 2004), 11

8 Asrori \& Munawir, Anomali Perilaku Remaja: Dialekitika Fitrah Manusia dan Pendidikan Islam, (Malang: Literasi Nusantara, 2020), 95
} 
perlu adanya usaha, kegiatan, cara, alat dan lingkungan hidup yang menunjang keberhasilannya. $^{9}$

\section{Metode Penelitian}

Jenis penelitian ini adalah penelitian tindakan kelas (PTK), Menurut Asrori, penelitian tindakan kelas adalah sebuah kegiatan yang dilaksanakan untuk mengamati kejadian- kejadian dalam kelas terbingkai dalam beberapa waktu atau siklus dengan metode kontekstual artinya variable-variable yang akan dipahami selalu berkaitan dengan kondisi kelas itu sendiri. Penelitian tindakan kelas bukan hanya bertujuan mengungkap penyebab berbagai permasalahan pembelajaran yang dihadapi seperti kesulitan siswa mempelajari pokok pembahasan tertentu, tetapi lebih penting lagi adalah memberikan pemecahan masalah berupa tindakan tertentu untuk meningkatkan kualitas proses dan hasil belajar. ${ }^{10}$

1. Rencana Penelitian

Rancangan peneliti ini dipilih karena memiliki karakteristik yang sesuai dengan tujuan penelitian yakni untuk meningkatkan prestasi belajar pada siswa Broken Home. Menurut penelitian tindakan adalah suatu bentuk penelitian refleksi diri secara kolektif yang melibatkan partisipasi guru, murid dan kepala sekolah dalam situasi social dengan tujuan untuk mengembangkan pendidikan sebagaimana telah dialami sehari-hari.

\section{Subjek Penelitian}

Subjek penelitian adalah siswa broken home di Phadungsil Wittaya School sebagai berikut: Kelas 4 sebanyak 6 siswa, Kelas 5 sebanyak 3 siswa, Kelas 6 sebanyak 4 siswa, Kelas 7 sebanyak 3 siswa, Kelas 8 sebanyak 3 siswa.

\section{Metode Pengumpulan Data}

Pengumpulan data dilakukan dengan menggunakan instrument utama dan instrument penunjang, instrument utama adalah peneliti sebagaimana yang dikemukakan oleh Bogdan dan Biklen bahwa peneliti adalah orang yang paling mengetahui seluruh data dan cara menyikapinya. Adapun instrument penunjang adalah pedoman observasi, catatan lapangan, dokumentasi dan foto. ${ }^{11}$

\footnotetext{
${ }^{9}$ Zakiyah Darajat \& dkk, Ilmu Pendidikan Islam, (Jakarta: Bumi Aksara, 1992), 28

${ }^{10}$ Asrori \& Rusman, Classroom Action Research Pengembangan Kompetensi Guru, (Purwokerto: Pena Persada, 2020), 5

${ }^{11}$ Suharsimin Arikunto, Manajemen Pendidikan, (Jakarta: Rineka Cipta, 2000), 35
} 
a. Penyimpulan Data

Kegiatan penyimpulan hasil penelitian dilakukan dengan menafsirkan makna suatu fenomena yang terjadi selama tindakan berlangsung, mencatat keteraturan, kecenderungan atau pola-pola tertentu, menjelaskan hubungan sebab akibat dan pada akhirnya menarik kesimpulan sementara. Untuk menafsirkan dan mengumpulkan hasil penelitian ditentukan kriteria-kriteria keberhasilan penelitian pada hasil pembelajaran yang dilihat dari hasil tes pada setiap akhir pembelajaran. Kriteria keberhasilan adalah skor rata-rata yang dicapai siswa pada kualifikasi baik (B) sampai dengan sangat baik (SB). ${ }^{12}$ Sebagaimana table berikut ini:

Tabel 1: Skor Rata-Rata

\begin{tabular}{|c|c|c|c|}
\hline $\begin{array}{c}\text { Pencapaian Tujuan } \\
\text { Pembelajaran }\end{array}$ & Skor Nilai & Kualifikasi & $\begin{array}{c}\text { Tingkat Keberhasilan } \\
\text { Pembelajaran }\end{array}$ \\
\hline $90-100 \%$ & $9-10$ & Sangat Baik (SB) & Berhasil \\
$70-89 \%$ & $7-8$ & Baik (B) & Berhasil \\
$50-69 \%$ & $5-6$ & Cukup (C) & Tidak Berhasil \\
$49 \%<$ & $4<$ & Kurang (K) & Tidak Berhasil \\
\hline
\end{tabular}

\section{b. Observasi Tindakan}

Pengamatan terhadap tindakan pembelajaran dilakukan secara sistematis, cermat dan obyektif. Pengamatan dilakukan secara menyeluruh dan difokuskan terhadap masalah-masalah penelitian. Semua data hasil pengamatan didokumentasikan dalam bentuk Chek dan catatan lapangan.

c. Refleksi

Pada setiap akhir pelaksanaan tindakan siklus I, siklus II dan siklus III peneliti mengadakan refleksi dengan jalan mendiskusikan tindakan yang telah dilaksanakan dengan temuan guru.

\section{Hasil dan Analisis Peneliian}

1. Siklus I

a. Perencanaan Siklus I

Pada pertemuan pertama tema yang diambil adalah pengertian Rukun Islam. Materi pembelajaran pertama adalah mengambil tema bacaan. Sumber belajar adalah buku tuntunan shalat, gambar orang shalat dan buku PAI untuk siswa. Pertemuan kedua mengambil tema gerakan sholat pembelajaran adalah bacaan dalam shalat,

${ }^{12}$ Albertus Heriyanto, Panduan Penelitian, (Jakarta: Prestasi Pustaka, 1998), 36 
sumber belajar adalah buku tuntunan shalat, gambar orang shalat dan buku PAI untuk siswa.

b. Pelaksanaan Siklus I

Pelaksanaan pembelajaran pada siklus 1 menerangkan tentang arti Rukun Islam dan penjelasannya. Guru memilih metode NLP untuk menjelaskan kepada siswa Broken Home. Karna siswa Broken Home sulit memahami pelajaran dan sulit untuk di ajak belajar.

\section{c. Observasi Tindakan}

Pada siswa dari pembelajaran yang dilakukan keberhasilan tindakan adalah $37 \%$ atau berada pada kualifikasi kurang. Tindakan yang dilakukan guru adalah memberi soal siswa tentang Rukun Islam. Kemampuan untuk mengerti arti Rukun Islam dengan menggunakan Bahasa Indonsia siswa Broken Home masih sangat rendah nilai yang dicapai masih sangat rendah.

Tabel 2: Siklus 1 Dari Minggu Ke-I

\begin{tabular}{|c|c|c|c|c|c|c|}
\hline No & Nama & Nilai & $\begin{array}{c}\text { Sangat Baik } \\
\text { (SK) }\end{array}$ & $\begin{array}{c}\text { Baik } \\
\text { (B) }\end{array}$ & $\begin{array}{c}\text { Cukup } \\
\text { (C) }\end{array}$ & $\begin{array}{c}\text { Kurang } \\
\text { (K) }\end{array}$ \\
\hline 1 & Suhaila ala mama' & 9 & $\mathrm{~V}$ & & & \\
\hline 2 & Nisrin Yusuf & 5 & & & V & \\
\hline 3 & Subaiyah Ma'ludiq & 6 & & & $\mathrm{~V}$ & \\
\hline 4 & Nurihan Mayu' & 4 & & & & $\mathrm{~V}$ \\
\hline 5 & Suraiyah Je'nuh & 7 & & $\mathrm{~V}$ & & \\
\hline 6 & Nurhayati Dusu' & 6 & & & $\mathrm{~V}$ & \\
\hline 7 & Nurhayati Sidiq & 4 & & & & V \\
\hline 8 & Fatimah Ma'di & 4 & & & & V \\
\hline 9 & Waru' Ni Dusuk & 5 & & & $\mathrm{~V}$ & \\
\hline 10 & Afnan Tho'yok & 9 & $\mathrm{~V}$ & & & \\
\hline 11 & Sofyadi Waswak & 7 & & V & & \\
\hline 12 & Sufiyani Fa'ka & 8 & & $\mathrm{~V}$ & & \\
\hline 13 & Nurida Lahi & 5 & & & $\mathrm{~V}$ & \\
\hline 14 & Albukhori Maghin & 4 & & & & $\mathrm{~V}$ \\
\hline 15 & Ilham Yahu' & 4 & & & & V \\
\hline 16 & Masani Tuksatu & 4 & & & & V \\
\hline 17 & Furqon Fa'ka & 7 & & $\mathrm{~V}$ & & \\
\hline 18 & Dismi Mayi’ & 6 & & & $\mathrm{~V}$ & \\
\hline 19 & Afnan Yusuf & 8 & $\mathrm{~V}$ & & & \\
\hline
\end{tabular}

$\mathrm{SB}=3$ Siswa

$\underline{B=4 \text { Siswa }}+$

Prosentase: $7 \times 100 \%=37 \%$

19 
Tabel 3: Siklus 1 Dari Minggu Ke 2

\begin{tabular}{|l|l|c|c|c|c|c|}
\hline No & \multicolumn{1}{|c|}{ Nama } & Nilai & $\begin{array}{c}\text { Sangat Baik } \\
\text { (SK) }\end{array}$ & $\begin{array}{c}\text { Baik } \\
\text { (B) }\end{array}$ & $\begin{array}{c}\text { Cukup } \\
\text { (C) }\end{array}$ & $\begin{array}{c}\text { Kurang } \\
\text { (K) }\end{array}$ \\
\hline 1 & Suhaila ala mama' & 9 & V & & & \\
\hline 2 & Nisrin Yusuf & 9 & V & & & \\
\hline 3 & Subaiyah Ma'ludiq & 6 & & & V & \\
\hline 4 & Nurihan Mayu' & 4 & & & & V \\
\hline 5 & Suraiyah Je'nuh & 7 & & V & & \\
\hline 6 & Nurhayati Dusu' & 6 & & & V & \\
\hline 7 & Nurhayati Sidiq & 7 & & V & & \\
\hline 8 & Fatimah Ma'di & 4 & & & & V \\
\hline 9 & Waru' Ni Dusuk & 5 & & & V & \\
\hline 10 & Afnan Tho'yok & 9 & V & & & \\
\hline 11 & Sofyadi Waswak & 8 & & V & & \\
\hline 12 & Sufiyani Fa'ka & 9 & V & & & \\
\hline 13 & Nurida Lahi & 5 & & & V & \\
\hline 14 & Albukhori Maghin & 7 & & V & & \\
\hline 15 & Ilham Yahu' & 4 & & & & V \\
\hline 16 & Masani Tuksatu & 4 & & & & V \\
\hline 17 & Furqon Fa'ka & 7 & & V & & \\
\hline 18 & Dismi Mayi' & 6 & & & V & \\
\hline 19 & Afnan Yusuf & 9 & V & & & \\
\hline
\end{tabular}

$\mathrm{SB}=5$ Siswa

$\underline{B}=5$ Siswa +

10 Siswa

Prosentase: $10 \times 100 \%=62 \%$

19

\section{d. Refleksi Tindakan}

Pada pembelajaran siklus 1 hasil refleksi yang penulis peroleh yaitu: Pada saat pembelajaran materi tentang Rukun Islam berlangsung siswa tidak tenang dan banyak berbicara sendiri. Kegiatan membimbing siswa dalam mengerti arti Rukun Islam dengan baik dan benar perlu lebih ditingkatkan lagi. Hasil belajar secara keseluruhan pada pembelajaran siklus 1 minggu pertama kualifikasi kurang, dan Minggu ke 2 pada kualifikasi cukup. Dari Minggu pertama dan Minggu kedua ada peningkatan.

2. Siklus II

a. Perencanaan Siklus II

Pada pertemuan Selanjutnya tema yang diambil adalah pengertian Rukun Iman. Materi pembelajaran pertama adalah mengambil tema Rukun Iman yang ke1 sampai ke3. Sumber belajar adalah buku siswa Pendidikan Agama Islam. Pertemuan kedua mengambil tema Rukun Iman yang ke4 sampai ke6. Sumber belajar adalah buku siswa Pendidikan Agama Islam. 
b. Pelaksanaan Siklus III

Pertemuan pertama, guru mengajarkan dan menerangkan arti Rukun Iman dengan urutannya. Guru memberi waktu siswa untuk membaca dan memahami arti Rukun Iman yang ke1 sampai ke3. Pertemuan kedua, guru mendemonstrasikan beberapa pelajaran yang telah di ajarkan dipertemuan pertama.

c. Observasi Tindakan Siklus II

Tingkat pencapaian proses pembelajaran Rukun Imaan dengan menggunakan Metode NLP siswa dapat mencapai $68 \%$ dan pada siklus I hanya $62 \%$. Pencapaian tingkat ketuntasan klasikal adalah bahwa pada siklus II tingkat ketuntasan 74\% dari seluruh siswa dan pada siklus II tingkat ketuntasan $84 \%$ dari seluruh siswa.

Tabel 4: Siklus II Dari Minggu Ke1

\begin{tabular}{|l|l|c|c|c|c|c|}
\hline No & \multicolumn{1}{|c|}{ Nama } & Nilai & $\begin{array}{c}\text { Sangat Baik } \\
\text { (SK) }\end{array}$ & $\begin{array}{c}\text { Baik } \\
\text { (B) }\end{array}$ & $\begin{array}{c}\text { Cukup } \\
(\mathbf{C})\end{array}$ & $\begin{array}{c}\text { Kurang } \\
\text { (K) }\end{array}$ \\
\hline 1 & Suhaila ala mama' & 9 & V & & & \\
\hline 2 & Nisrin Yusuf & 9 & V & & & \\
\hline 3 & Subaiyah Ma'ludiq & 6 & & & V & \\
\hline 4 & Nurihan Mayu' & 9 & V & & & \\
\hline 5 & Suraiyah Je'nuh & 7 & & V & & \\
\hline 6 & Nurhayati Dusu' & 8 & & V & & \\
\hline 7 & Nurhayati Sidiq & 7 & & V & & \\
\hline 8 & Fatimah Ma'di & 4 & & & & V \\
\hline 9 & Waru' Ni Dusuk & 5 & & & V & \\
\hline 10 & Afnan Tho'yok & 9 & V & & & \\
\hline 11 & Sofyadi Waswak & 8 & & V & & \\
\hline 12 & Sufiyani Fa'ka & 9 & V & & & \\
\hline 13 & Nurida Lahi & 5 & & & V & \\
\hline 14 & Albukhori Maghin & 7 & & V & & \\
\hline 15 & Ilham Yahu' & 5 & & & V & \\
\hline 16 & Masani Tuksatu & 8 & & V & & \\
\hline 17 & Furqon Fa'ka & 7 & & V & & \\
\hline 18 & Dismi Mayi & 8 & & V & & \\
\hline 19 & Afnan Yusuf & 9 & V & & & \\
\hline SB & $=$ 6 Siswa \\
B & 8 Siswa + & & & & & \\
\hline
\end{tabular}

Prosentase: $14 \times 100 \%=74 \%$

19

Tabel 5: Siklus II Dari Minggu Ke 2

\begin{tabular}{|l|l|c|c|c|c|c|}
\hline No & \multicolumn{1}{|c|}{ Nama } & Nilai & $\begin{array}{c}\text { Sangat Baik } \\
\text { (SK) }\end{array}$ & $\begin{array}{c}\text { Baik } \\
(\mathbf{B})\end{array}$ & $\begin{array}{c}\text { Cukup } \\
(\mathbf{C})\end{array}$ & $\begin{array}{c}\text { Kurang } \\
(\text { K) }\end{array}$ \\
\hline 1 & Suhaila ala mama' & 9 & V & & & \\
\hline 2 & Nisrin Yusuf & 9 & V & & & \\
\hline 3 & Subaiyah Ma'ludiq & 7 & & V & & \\
\hline
\end{tabular}




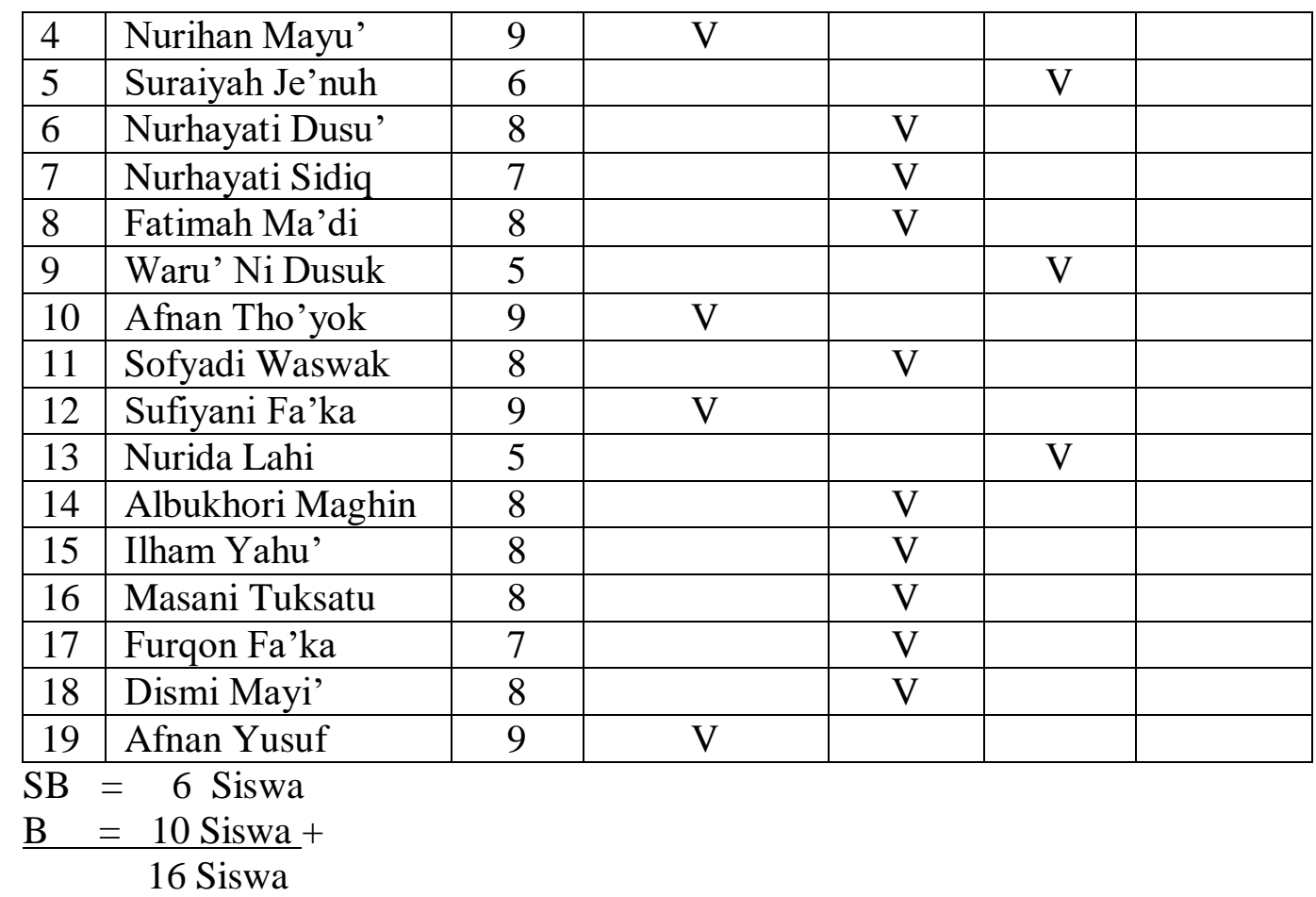

Prosentase: $16 \times 100 \%=84 \%$

19

\section{d. Refleksi Tindakan Siklus II}

Saat pembelajaran Rukun Iman sedang berlangsung siswa Broken Home memperhatikan pembelajaran yang sedang berlangsung. Hal ini diduga karena metode NLP untuk meningkatkan hasil belajar siswa. Hasil pembelajaran secara keseluruhan mengalami peningkatan terbukti hasil rata-rata prosentase berada pada kualifikasi baik. Setelah analisis dan refleksi yang dilakukan pada siklus II ditemukan peningkatan baik aktifitas maupun kemampuan siswa, meskipun masih ada beberapa yang harus ditingkatkan.

\section{Siklus III}

a. Perencanaan Siklus III

Pada pertemuan Selanjutnya tema yang diambil adalah pengertian Rukun Islam dan Rukun Iman. Materi pembelajaran pertama adalah pengulangan dan penguatan Rukun Islam. Sumber belajar adalah buku siswa Pendidikan Agama Islam. Pertemuan kedua mengambil tema penguatan tentang Rukun Iman. Sumber belajar adalah buku siswa Pendidikan Agama Islam.

b. Pelaksanaan Siklus III

Pertemuan pertama, guru mengulangi materi Rukun Islam. Guru memberi waktu siswa untuk membaca dan memahami arti Rukun Islam dengan baik dan benar. 
Pertemuan kedua, guru mengulangi materi Rukun Iman. Guru memberi waktu siswa untuk membaca dan memahami arti Rukun Iman dengan baik dan benar.

c. Observasi Tindakan Siklus III

Tingkat pencapaian proses pembelajaran Rukun Islam dan Rukun Iman dengan menggunakan Metode NLP siswa dapat mencapai $68 \%$ dan pada siklus I hanya $62 \%$. Pencapaian tingkat ketuntasan klasikal adalah bahwa pada siklus II tingkat ketuntasan $74 \%$ dari seluruh siswa dan pada siklus III tingkat ketuntasan 95\% dari seluruh siswa.

Tabel 6: Siklus III Pada Minggu Ke 2

\begin{tabular}{|l|l|c|c|c|c|c|}
\hline No & \multicolumn{1}{|c|}{ Nama } & Nilai & $\begin{array}{c}\text { Sangat Baik } \\
\text { (SK) }\end{array}$ & $\begin{array}{c}\text { Baik } \\
(\text { B })\end{array}$ & $\begin{array}{c}\text { Cukup } \\
(\mathbf{C})\end{array}$ & $\begin{array}{c}\text { Kurang } \\
(\mathbf{K})\end{array}$ \\
\hline 1 & Suhaila ala mama' & 9 & V & & & \\
\hline 2 & Nisrin Yusuf & 9 & V & & & \\
\hline 3 & Subaiyah Ma'ludiq & 7 & & V & & \\
\hline 4 & Nurihan Mayu' & 9 & V & & & \\
\hline 5 & Suraiyah Je'nuh & 6 & & & V & \\
\hline 6 & Nurhayati Dusu' & 8 & & V & & \\
\hline 7 & Nurhayati Sidiq & 7 & & V & & \\
\hline 8 & Fatimah Ma'di & 8 & & V & & \\
\hline 9 & Waru' Ni Dusuk & 5 & & & V & \\
\hline 10 & Afnan Tho'yok & 9 & V & & & \\
\hline 11 & Sofyadi Waswak & 8 & & V & & \\
\hline 12 & Sufiyani Fa'ka & 9 & V & & & \\
\hline 13 & Nurida Lahi & 9 & V & & & \\
\hline 14 & Albukhori Maghin & 8 & & V & & \\
\hline 15 & Ilham Yahu' & 8 & & V & & \\
\hline 16 & Masani Tuksatu & 8 & & V & & \\
\hline 17 & Furqon Fa'ka & 7 & & V & & \\
\hline 18 & Dismi Mayi' & 8 & & V & & \\
\hline 19 & Afnan Yusuf & 9 & V & & & \\
\hline
\end{tabular}

$\mathrm{SB}=7$ Siswa

$\underline{B}=10$ Siswa +

17 Siswa

Prosentase: $17 \times 100 \%=89 \%$

19

Tabel 7 Siklus III Dari Minggu Ke 2

\begin{tabular}{|l|l|c|c|c|c|c|}
\hline No & \multicolumn{1}{|c|}{ Nama } & Nilai & $\begin{array}{c}\text { Sangat Baik } \\
\text { (SK) }\end{array}$ & $\begin{array}{c}\text { Baik } \\
(\text { B })\end{array}$ & $\begin{array}{c}\text { Cukup } \\
(\mathbf{C})\end{array}$ & $\begin{array}{c}\text { Kurang } \\
(\text { K) }\end{array}$ \\
\hline 1 & Suhaila ala mama' & 9 & V & & & \\
\hline 2 & Nisrin Yusuf & 9 & V & & & \\
\hline 3 & Subaiyah Ma'ludiq & 7 & & V & & \\
\hline 4 & Nurihan Mayu' & 9 & V & & & \\
\hline 5 & Suraiyah Je'nuh & 7 & & V & & \\
\hline 6 & Nurhayati Dusu' & 8 & & V & & \\
\hline
\end{tabular}




\begin{tabular}{|l|l|l|l|c|l|l|}
\hline 7 & Nurhayati Sidiq & 7 & & V & & \\
\hline 8 & Fatimah Ma'di & 8 & & V & & \\
\hline 9 & Waru' Ni Dusuk & 5 & & & V & \\
\hline 10 & Afnan Tho'yok & 9 & V & & & \\
\hline 11 & Sofyadi Waswak & 8 & & V & & \\
\hline 12 & Sufiyani Fa'ka & 9 & V & & & \\
\hline 13 & Nurida Lahi & 9 & V & & & \\
\hline 14 & Albukhori Maghin & 8 & & V & & \\
\hline 15 & Ilham Yahu' & 8 & & V & & \\
\hline 16 & Masani Tuksatu & 8 & & V & & \\
\hline 17 & Furqon Fa'ka & 7 & & V & & \\
\hline 18 & Dismi Mayi' & 8 & & V & & \\
\hline 19 & Afnan Yusuf & 9 & V & & & \\
SB $=$ 7 Siswa \\
B 11 Siswa +
\end{tabular}

Prosentase: $18 \times 100 \%=95 \%$

19

\section{d. Refleksi Tindakan Siklus III}

Saat pembelajaran Rukun Iman dan Rukun Islam sedang berlangsung siswa Broken Home memperhatikan pembelajaran yang sedang berlangsung. Hal ini diduga karena metode NLP untuk meningkatkan hasil belajar siswa. Hasil pembelajaran secara keseluruhan mengalami peningkatan terbukti hasil rata-rata prosentase berada pada kualifikasi cukup baik. Setelah analisis dan refleksi yang dilakukan pada siklus III ditemukan peningkatan baik aktifitas maupun kemampuan siswa.

Temuan pertama penggunaan metode NLP ini sangat penting untuk meningkatkan prestasi belajar pada siswa Broken Home. Karena dengan metode NLP ini dapat membuat siswa menurut apa yang guru inginkan. Metode NLP memberikan pengalaman pada siswa untuk bisa sabar dan iklas menghadapi apa yang terjadi kepada mereka. Temuan kedua, berkaitan dengan pembelajaran yang digunakan oleh guru. Tindakan pembelajaran menggunakan proses pembelajaran dalam format NLP.

\section{Kesimpulan dan Rekomendasi}

1. Kesimpulan

Metode NLP adalah salah satu cara komunikasi yang digunakan untuk mendidik atau mengarahakan anak didik yang wajib dimiliki tenaga pendidik sehingga dapat menggali potensi yang tersembunyi. Maka metode NLP dalam mengatasi anak 
Broken Home sangatlah penting, Karena anak Broken Home memiliki sifat yang cenderung tertutup sehingga potensi diri anak Broken Home sulit untuk di tampilkan.

Prestasi siswa Broken Home pada pelajaran Pendidikan Agama Islam sebelum mengunakan metode komunikasi NLP sangat rendah ditinjau dari siklus 1, setelah menerapakan metode komunikasi NLP di tinjau dari Siklus 2, dan hasil yang baik hingga sempurna pada pelajaran Pendidikan Agama Islam di tampilkan setelah menggunakan metode NLP dengan baik yang dapat di tinjau dari Siklus 3.

Peningkatan metode NLP sangat berpengaruh dan berkembang pesat dalam perkembangan prestasi siswa Broken Home, dimulai sebelum menerapkan metode NLP prestasi yang didapat siswa Broken Home sangatlah rendah dan belum memasuki kriteria baik, dapat di tinjau dari tahab pertama Siklus I dengan nilai cukup skor $62 \%$. Tahab kedua Siklus II dengan nilai Baik skor $84 \%$. Tahab terakhir Siklus III dengan nilai sangat baik dengan skor $95 \%$.

2. Rekomendasi

Guru diharapkan mampu mengunakan dan mengembangkan metode komunikasi NLP karena mengatasi anak Broken Home, karena anak Broken Home memiliki sifat yang cenderung tertutup sehingga potensi diri anak Broken Home sulit untuk di tampilkan. Tetapi tidak hanya anak Broken Home saja nanti diharapkan bisa dikembangkan dalam menagani problematika-problematika yang dihadapi siswa dalam proses pembelajaran

\section{Referensi}

Albertus Heriyanto. 1998. Panduan Penelitian. Jakarta: Prestasi Pustaka

Arikunto, Suharsimin. 2000. Manajemen Pendidikan. Jakarta: Rineka Cipta

Asrori \& Munawir. 2020. Anomali Perilaku Remaja: Dialekitika Fitrah Manusia dan Pendidikan Islam. Malang: Literasi Nusantara

Asrori \& Rusman. 2020. Classroom Action Research Pengembangan Kompetensi Guru, Purwokerto: Pena Persada

Dilts, R dan Delozier. 2000. Enyclopedia of Systemic NLP an NLP New Coding. USA: NLP University Press

Ghannoe. 2010. Buku pintar NLP. Jogjakarta: FlashBook

Harris, C. 2003. NLP Made Easy. London: Element 
Heriyanto, Albertus.1998. Panduan Penelitian, Jakarta: Prestasi Pustaka.

J.P Chaplin. 2005. Kamus Lengkap Psikologi. Raja Grafindo Persada

Kulliyatul Mu'allimah Al Islamiah. 2007. Usulul Attarbiyah Wata'lim Jus Assani, Ponorogo: Pondok Modern Darussalam Gontor

Save. M. Dagun. 2002. Psikologi Keluarga Jakarta, Rieneka Cipta

Suharsimin Arikunto. 2002 Manajemen Pendidikan. Jakarta: Rineka Cipta

Zakiyah Darajat \& dkk. 1992 Ilmu Pendidikan Islam. Jakarta: Bumi Aksara

Zuhairini. 2004. Metodologi Pembelajaran Pendidikan Agama Islam. Malang: UIN Press 